20才，男子に上顎洞の反復穿刺洗滌により，慢性絲球体腎炎を急速に軽快させた症例を報告した。 擱筆に当り，御校閲を賜つた恩師後藤教授および当教室講師高橋博上に深謝する.

本交要旨は耳喉科関西地方会第37回例会において発表した。

\title{
参考交 献
}

1）長谷川：日耳会 $\mathbf{5 8 , 5}$, 昭 26 .

15.

2）岡林：日病学会，37, 138, 174, 昭 15 .

3）後藤光治：耳鼻臨床, $.44,1$, 昭 26.

9) Nühsmann : H-N-O. heilk. (Denker u. Kahler 2, 706, 1926.

4）豊田：耳鼻臨床， 50，10，32，昭32.

5）滝田：耳喉科，28,3,31,

10) Gutzeit u. Parade : Erg. inn. Med. u. Kind hk. 57, 613, 1939.

6）天野：日病会誌，38, 1. 15. 昭 24 .

7）豊田：日耳鼻，41，12，1565，昭10.

11) Scheifferth u. Bulitta : Deutsche Med. Wschr. 78, 26, 948, 1953.

\section{洞 性 後鼻孔鼻茸の 5 症例}

$$
\text { 松森 晨一* ・ 乾修* }
$$

緒

言

洞性後鼻孔鼻苜については Killian ${ }^{17)}$, 久保 (猪) ${ }^{10)}$ を始め多数の報告があるが, 最近我々の相次 いで経験した 5 症例に対し主として病理組織学的検索を試みたので, その得た成績を報告し, 若干 の考察を試みて参考に資するものである。

症

例

症例 I

\section{患者 : 22才 우}

初診 : 昭和 34 年 3 月 16 日

主訴：左側鼻閉

既往歴 : 約 7 年前左側鼻咠切除術を受く.

現病歴：約 10 力月前より左側鼻閉，後鼻漏，嗅覚減 退あり。

現症 : 全身所見，異常無し. 局所所見，左側中鼻道 および後鼻孔に鼻茸を認む. Fränkel検査(以下F.V. 之略) 両側 $(\rightarrow$

\section{症例 II}

患者
9 才令
初診 : 昭和 34 年 3 月 25 日

主訴：両側鼻閉

既往歴：約10回両側鼻茸切除術を受く.

現病歴: 約 3 年前より両側鼻閉，鼻漏あり.

現症 : 全身所見, 異常無し. 局所所見, 左側中鼻道 および後鼻孔に鼻茸を認む。.F.V.両側 $($ （附図 3 )

症例 'III

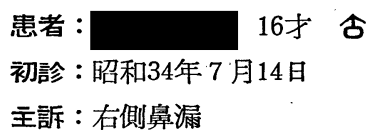

既往歴：約 7 年前右側甲介切除術を受く.

現病歴：約 7 年前より右側鼻漏，鼻閉，後鼻漏あ

* 奈良県立医科大学耳鼻咽唉科学教室（主任 内海貞夫教授） 
り.

現症：全身所見，異常無し。

局所所見, 右側中甲介腫脹, 鼻中隔左方彎曲

右中鼻道に鼻茸あり．F. V. 右(十)左 $(\rightarrow$

\section{症例 IV}

患者：15才古

初診：昭和 34 年 7 月 21 日

主訴：両側鼻閉

既往歴：約 2 年前両側慢性副鼻腔炎の診断を受く.

現病厢: 幼少時より両側鼻閉, 鼻漏, 頭重, 嗅覚減 退あり。

現症：全身所見異常無し. 局所所見, 両側中甲介腫 脹, 右中鼻道に鼻茸を認む, 後鼻漏あり. F. V. 両側 (H) (附図 1)

\section{症例 $\mathbf{V}$}

患者：11才含

初診：昭和34年 7 月 22 日

主訴：左側鼻閉および鼻腔内腫瘤

既往歴：約 2 年前左側鼻茸切除術を受く.

現病歴：約 3 年前より左側鼻閉あり。

現症：全身所見 異常無し.

局所所見 左側中甲介腫脹，左側中鼻道およ び後鼻孔に鼻茸を認む．F. V. 左け（附図 2)

\section{検查所見}

レントゲン検查：症例IVは両側に，他の 4 症例は鼻 耳側に濔漫性陰影を認む。

血液検查 : 異常なく好酸球数も第 1 表のごとくほほ 正常.

Thorn's test： 5 例ともに陰性.

第 I 表

\begin{tabular}{|c|c|c|c|}
\hline 症 例 & 列. & 好酸 球 & 百分率 \\
\hline \multirow[t]{5}{*}{ 症＼cjkstart例 } & I & $: 7$ & $\%$ \\
\hline & II & 5 & $\%$ \\
\hline & III & 2. & $\%$ \\
\hline & IV & 4 & $\%$ \\
\hline & V & 3 & $\%$ \\
\hline
\end{tabular}

\section{手術所見}

何れもLuc Caldwell 法に從い上顎洞根治手術を行 い，洞粘膜および鼻茸を同時に摘出した．所見は下記 の通りである.

症例 I. 洞内容物として漿液性物質約 $3 \mathrm{cc}$ あり, 洞 粘膜は浮腫状. 鼻咠大きさ $4 \times 2 \times 2 \mathrm{~cm}$.
症例.I. 漿液性物質䄪 $4 \mathrm{cc}$. 洞粘膜は線維状，所に より浮腫状を呈す，鼻茸は 2 つに分岐して大きさ $2 \times$ $3 \times 2 \mathrm{~cm}$

症例III. 漿液性物質約 $20 \mathrm{cc}$. 洞粘膜は線維状所によ り浮腫状を呈す．鼻茸大きさ $1.5 \times 1.5 \times 1.5 \mathrm{~cm}$

症例IV. 漿液性物質約 $2 \mathrm{cc}$. 洞粘膜は主として線維 状を呈し, 鼻咠は自然孔附近で一部強度に痹着す。鼻 革大きさ $1.5 \times 1 \times 3 \mathrm{~cm}$

症例 $\mathbf{V}$. 漿液性物質約 $3 \mathrm{cc}$. 洞粘膜は一般に浮腫状 を呈す．鼻茸大きさ $1.5 \times 3 \times 1.5 \mathrm{~cm}$

\section{病理組織学的所見}

標本は各症例につき洞粘膜, 茎部, 鼻茸の 3 力所より 作成し, 各々に Haematoxylin-Eosin 染色, Van Gieson 染色, Mallory染色，P. A. S. 反応，線維素染 色を行い，上皮細胞，上皮下組織，細胞漫潤，腺組織， 血管壁の変化を詳細に検討した. 所見の概要は第 2 表 のごとくである。すなわち上皮細胞は全例に涂離，脱 落，萎縮が著明であり，増殖も中等度認めるが，洞粘 膜部においては此較的軽度であり化生（扁平上皮化）

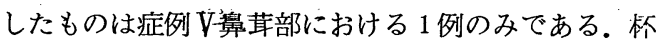
状細胞の出現は洞粘膜部茎部に軽度認めるが，鼻茸部 にはこれを全く認めない，細胞浸潤も全例ともにほほほ 同様の所見である. 乳嘴様増殖を第 1 例において洞粘 膜部，茎部に認めた。基礎膜肥厚は洞粘膜部，鼻茸部 に軽度に認めた。

上皮下には，浮腫，結合織の膨化，増殖が全例に著 しく，出血，硝子様変性を中等度に，また漿液性渗出 物の貯溜を認めた. 細胞浸潤は一般に認めるものであ るが，洞粘膜部においては症例 I に，茎部では症例 III IVに，㐭茸部では症例吕にそれぞれ特に著明であり， その種類はリンパ球が最も多く, 次に好酸球, 形質細 胞，好中球の順である。単球，組織球の浸潤は軽度に 認めたが，Russell 小体の出現を殆ど認めず，リンパ 滤胞の形成は全く認めない，腺組織においては分泌立 進，増殖も極めて稀である。变性，萎縮は洞粘膜部に おいて症例 III， $\mathbb{N}, V$ ，茎部において症例 $\mathbb{I}$ ，鼻茸にお いて症例 I，Vにそれぞれ著明に認めた。衰腫形成は 洞粘膜部で症例 IIIに，鼻茸部には症例 $\mathrm{V} に$ 認め，腺周 囲組織の細胞浸㵎は洞粘膜部にて僅かに認むのみであ る. 血管の新生および充血は全例に著明であつたが， 血管壁の膨化，肥厚は特に茎部において著しく，線維 素様変性は鼻茸部において僅かに症例Vにのみ認め た．血管壁の硝子化は全例に軽度認めるが，アミロイ ド化は見られなかつた。 


\begin{tabular}{|c|c|c|c|c|c|c|c|c|c|c|c|c|c|c|c|c|}
\hline \multirow{2}{*}{$\begin{array}{l}- \\
\text { 組 } \\
\text { 織 }\end{array}$} & 位 & & 同 & 粘 & 膜 & \multirow[b]{2}{*}{$\mathrm{V}$} & \multicolumn{3}{|c|}{ 茥 } & \multicolumn{2}{|c|}{ 部 } & \multicolumn{2}{|r|}{ 㐭 } & \multicolumn{2}{|c|}{ 茸 } & \multirow[b]{2}{*}{ V } \\
\hline & 見 例 & I & II & III & IV & & I & II & III & IV & $\mathrm{V}$ & I & II & III & IV & \\
\hline \multirow{4}{*}{$\begin{array}{l}\text { 上 } \\
\text { 皮 }\end{array}$} & 剩 離 脱 落 & + & $H$ & 世 & + & 卅 & + & W & 册 & 册 & 册 & 册 & H & 册 & 世 & H \\
\hline & 増 殖 & H & - & - & + & - & + & + & + & + & + & + & + & + & + & + \\
\hline & 萎＜wide>縮 & + & + & 世 & + & 卅 & + & m & \# & + & $H$ & + & H & m & + & + \\
\hline & 化 生 & - & - & - & - & - & - & - & - & - & - & - & - & - & - & + \\
\hline 細 & 杯 状 細 胞 & \pm & + & + & + & - & + & + & - & - & \pm & - & - & - & $\therefore$ & - \\
\hline \multirow[t]{2}{*}{ 胞 } & 細 胞 浸 潤 & - & - & - & - & - & + & - & - & - & - & 一 & - & - & 一 & - \\
\hline & 乳 嘴 形 成 & + & - & + & - & - & + & - & - & - & - & - & - & + & - & \pm \\
\hline 基 & 礎 膜 肥 厚 & - & \pm & + & + & + & - & - & \pm & - & - & - & + & H & + & - \\
\hline \multirow{5}{*}{$\begin{array}{l}\frac{上}{\text { 皮 }} \\
\text { 組 } \\
\text { 織 }\end{array}$} & 腫。 & + & + & + & 册 & + & + & m & 册 & m & 册 & W & $H$ & $H$ & 册 & 册 \\
\hline & 出 血 & + & + & + & + & $+:$ & + & + & - & 世 & 冊 & - & - & \pm & - & + \\
\hline & 結 合 織: 膨 化 & + & + & + & $H$ & + & + & W & 世 & W & 世 & W & $H$ & $H$ & 册 & 曲 \\
\hline & 結 合 織 増 殖 & H & $H$ & H & $H$ & H & + & W & $H$ & 册 & H & H & W & $H$ & m & 册 \\
\hline & 硝 子 様 変 性 & + & ï & H & + & + & - & + & + & + & + & + & + & + & + & 世 \\
\hline \multirow{7}{*}{$\begin{array}{l}\text { 細 } \\
\text { 胞 } \\
\text { 浸 } \\
\text { 潤 }\end{array}$} & 好 中 球 & + & \pm & + & + & - & \pm & + & + & + & \pm & + & + & \pm & + & 世 \\
\hline & リン パ 球 & H & H & H & 册 & H & W & H & 册 & 世 & 世 & 世 & H & H & H & + \\
\hline & 好 酸 球 & + & + & \pm & + & \pm & \pm & $H$ & + & $H$ & \pm & + & + & + & + & 册 \\
\hline & 形 質 細 胞 & + & + & + & $H$ & - & H & $H$ & + & $H$ & H & H & $H$ & H & + & + \\
\hline & 組織 球 & + & - & + & + & \pm & + & + & + & + & + & \pm & + & + & + & + \\
\hline & 単＼cjkstart球 & \pm & + & - & \pm & \pm & - & + & - & + & + & + & \pm & \pm & + & - \\
\hline & $\mathrm{R}$ 小 体 & - & + & - & + & - & - & - & - & - & + & \pm & + & - & - & - \\
\hline リ & ン パ 濾 胞 & - & - & - & - & - & - & - & - & - & - & - & - & - & - & - \\
\hline \multirow{5}{*}{$\begin{array}{l}\text { 腺 } \\
\text { 組 } \\
\text { 織 }\end{array}$} & 分 泌 六進 & - & - & + & - & - & - & - & - & - & - & - & - & - & - & - \\
\hline & 増＼cjkstart殖 & - & - & - & - & + & - & - & - & - & - & - & - & - & - & 一 \\
\hline & 変 性: 萎 縮 & - & - & + & H & + & - & + & - & - & - & H & - & - & - & \# \\
\hline & 斠 腫 形 成 & - & - & + & - & - & - & - & - & - & - & - & - & - & - & H \\
\hline & 周＼cjkstart囲 浸 潤 & - & - & + & + & - & - & - & - & - & - & - & - & - & - & 一. \\
\hline \multirow{2}{*}{$\begin{array}{l}\text { 血 } \\
\text { 管 }\end{array}$} & 新 & + & + & + & + & + & + & 冊 & + & $H$ & + & + & 世 & 卅 & + & + \\
\hline & 充 & + & + & m & + & W & m & W & + & m & 册 & + & m & W & + & + \\
\hline \multirow{5}{*}{$\begin{array}{l}\text { 血 } \\
\text { 管 } \\
\text { 壁 }\end{array}$} & & + & + & + & + & + & + & 册 & + & H & H & + & + & + & \pm & + \\
\hline & 膨 ＼cjkstart化 & H & - & - & + & - & + & + & $H$ & $H$ & + & + & + & + & W & + \\
\hline & 細＼cjkstart胞＼cjkstart浸＼cjkstart潤 & - & - & - & - & - & - & - & - & - & - & - & - & + & + & - \\
\hline & 線 維 素 変 性 & - & - & - & - & - & - & - & - & - & - & - & - & - & + & - \\
\hline & 硝 子 化 & + & + & + & + & + & - & + & \pm & + & + & + & + & + & + & + \\
\hline
\end{tabular}

\section{考}

以上洞性後番孔鼻茸の 5 症例について得た所見の大 要を述べた。

本 5 症例において鼻苗発生母地がいづれも与顎洞粘

\section{按}

膜部である事は手術所見より明かであり，久保(猪) ${ }^{10}$ の所説と一致して居る.

およそ一般に鼻茸の発生機序に関しては古くより， 
図 1 摘出せる洞性後鼻孔鼻茸（症例 IV)

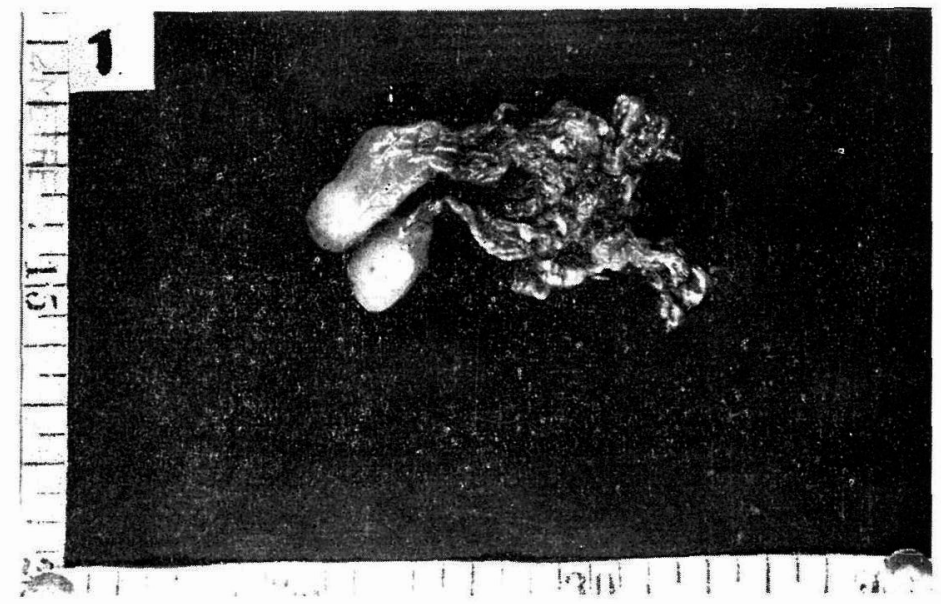

図 2 摘出せる洞性後鼻孔鼻茸（症例 V)

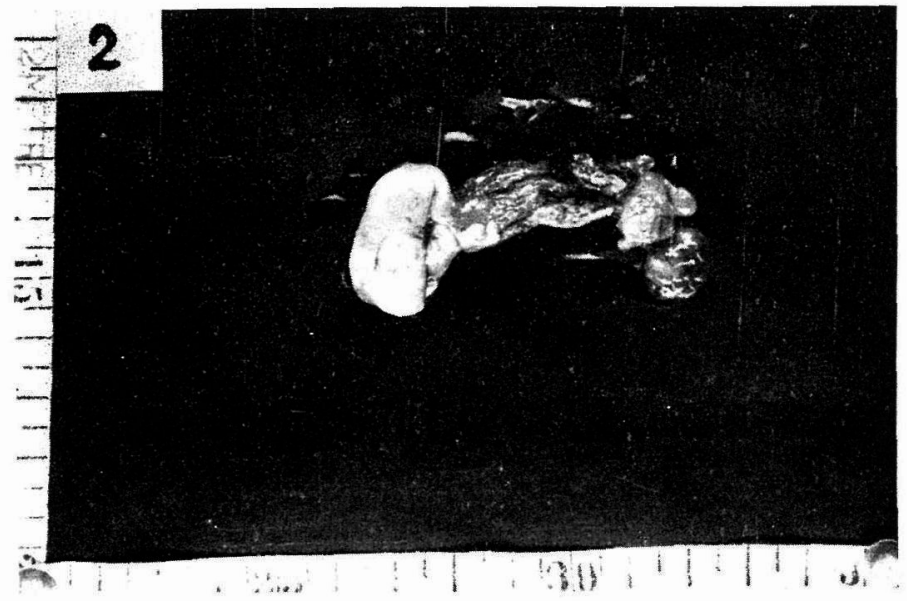

図 3 摘出せる洞性後鼻孔鼻荤（症例 $I I ）$

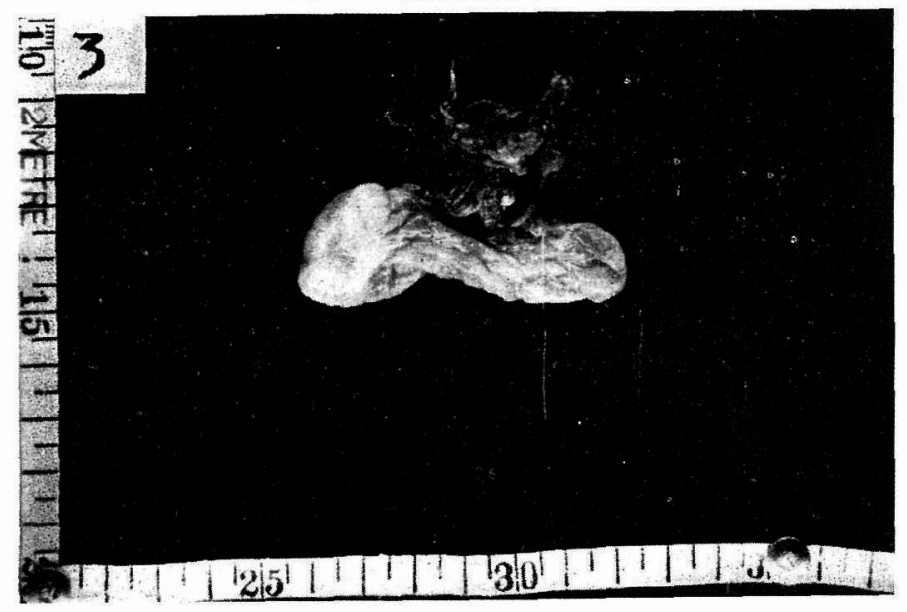


図 4 上皮下結合織の増殖，膨化，硝子㥞変性，細胞浸潤（症列 II 。鼻茸部 $\times 100$ )

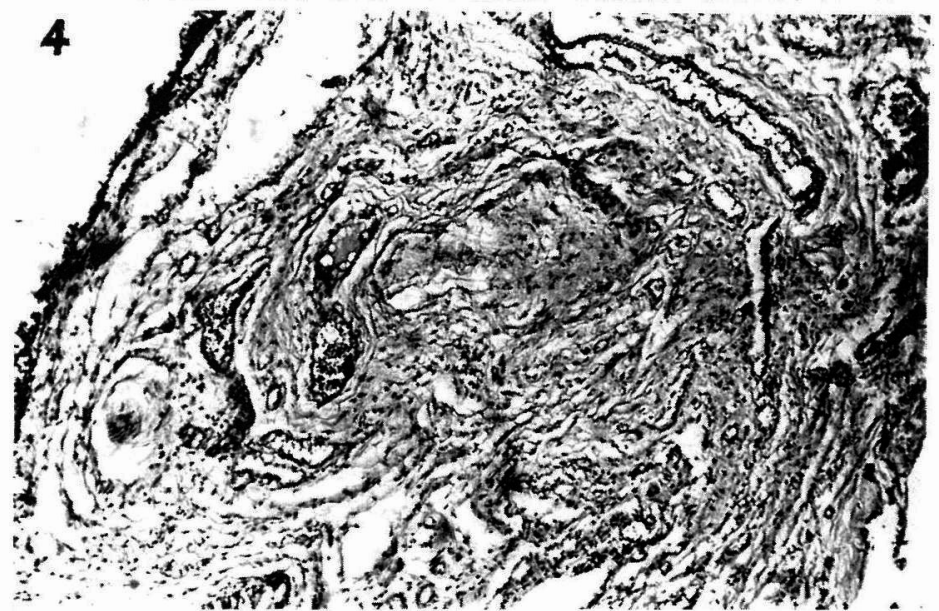

図 5 上皮の剝離，脱落，上皮下細胞浸㵎，浮腫（症例 V. 鼻茸部 $\times 200 ）$

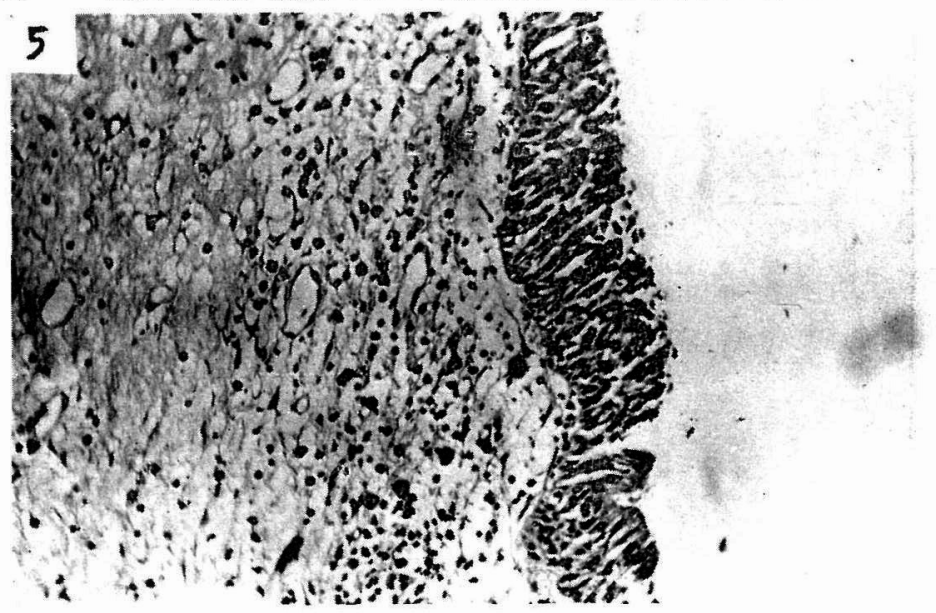

図 6 血管壁の膨化，肥厚，充血，上皮下の著明な浮腫、（症例 III．鼻茸部 $\times 200 ）$

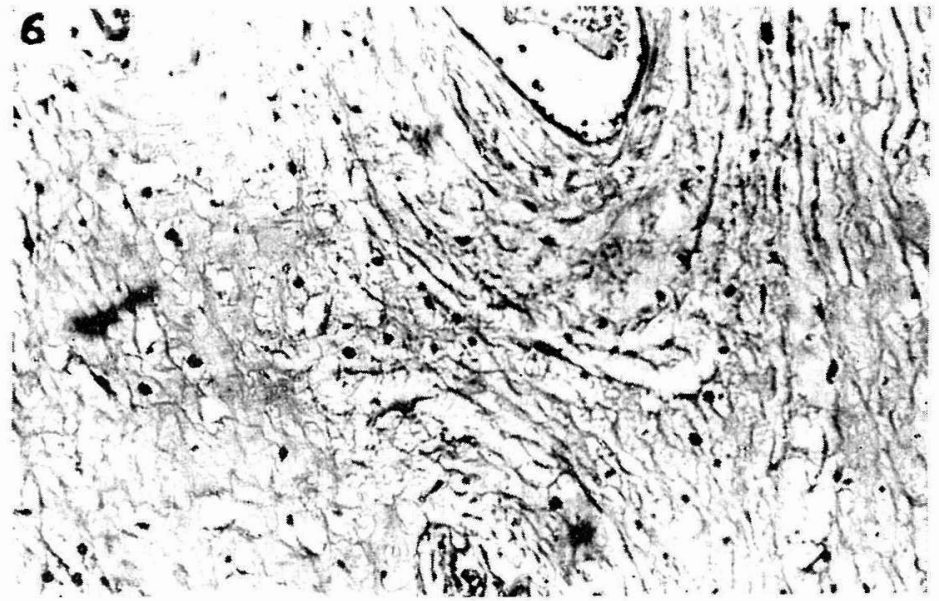


炎症説 (Fräkel) ${ }^{16)}$, Allergie 説 (Hansel) ${ }^{11) ; ~}$ 細菌説 (塩崎8), 粘膜に生じた小乳嘴状の突起の腫脹増大と考 えるもの(Heymann) ${ }^{14)}$, さらに腫瘍説(Billroth) ${ }^{15)}$ 至るまで極めて多く論ぜられているが，われわれの症 例の病理組織学的所見は要するに肉芽性炎症すなわち 器質化したものであり，少くともHansel ${ }^{11)}$ らの云う純 然たる漿夜性炎ではない.また Gerlach ${ }^{13)}$, 馬杉氏らの 唱えるAllergie性変化すなわち線維素様膨化などを殆 ど証明しないが, 高度の浮腫, 好酸球, プラスマ細胞 の浸潤，血管壁の膨化，硝子様変性などによつて， Allergie性変化をうかがい知る程度であり，これらの 所見より鼻茸発生の本態をAllergie と断定する事は本

\section{結}

症例においては困難である。

つぎに本症例では 5 例中 2 例に慢性上顎洞炎を高度 に伴つて居り，他の 3 例は軽度であつた，従つて慢性 上顎洞炎と鼻咠発生との相関関係につき断定すること も出来ない. 他方粘膜の乳嘴形成は本 5 症例において

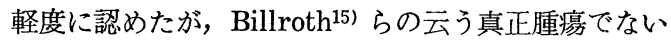
ことは病理組織学的所見より明白である.

以上要するにその発生原因は何れとも断定し難く, 果して Allergie によるものかあるいは他の因子によ るものか，またはこれらの組み合せによるものかは， なお将来の研究を要するものと考える.

1）洞性後鼻孔鼻茸の 5 症例につき主をして病理組織学的検索を行つた。

2) 各症例について洞粘膜, 茥部, 鼻茸の 3 カ所より標本を作成し比較検討した。

3）得た所見は肉芽性炎症であり，その鼻茸発生機序に関してなお今後検討を要するものと考え る.

本論文の要旨は，100 回耳鼻咽喉科学会大阪地方会にて発表した。終りに臨み，終始想篤なる指導と校閲を賜 つた内海貞夫教授ならびに本学病理学教室福岡善晃学士に蜾心から感謝する.

\section{主要 交 献}

1）渡辺道明：耳鼻臨床，48. 10, 56. 昭30.

2）山崎恭輔：日耳鼻，57, 9, 922. 928.931. 昭29.

3）管井保三 : 耳喉科，27，8，435. 昭30.

4）市原正雄・白倉賢三：耳侯科, 26, 9, 436. 昭 29 .

5）吉川精一: 耳喉科, 26, 72, 519. 昭 29 .

6）村島二郎・光増昭：日耳鼻, $5 \mathbf{6}, 8,591$. 昭 28.

7）仁保三四次他 : 耳喉科，23, 5, 11. 昭 26.

8）塩崎義郎：日耳鼻，39，8，956. 昭8.

9）白川吾一郎：アレルギーの立場から観た慢性副 鼻腔炎, 日本耳鼻咽喉科学会第58回総会宿題報 告より.

10）久保猪之吉：臨床耳鼻咽啹科学, 1940.
11) Hansel : Allergy of the Nose and Paranasal sinuses, 1936.

12) Anderson : Pathology, 1953.

13) Gerlach, W. : Virchows Arch., 247, 294, 1923.

14) Heymann, P. : Hand. d. Laryngo. u. Rhino. Bd. III, 806, 1900.

15) Billroth, D. : Über d. Bau d. Shleimpolyp. Berl. (Z. n. Schiosaki)

16) Fränkel, E: Virchows Arch. Bd. 143, 1896.

17） Killian：日本耳鼻咽喉科全書，第二巻，鼻腔 及び副鼻腔, 臨床編, 各論IV.397.より引用. 